\title{
Effect of Seaweed Liquid Fertilizer on Antioxidant and Enzyme Activity of Different Vegetables Seeds
}

\author{
Rinku V. Patel ${ }^{1,2}$, Nayana Brahmbhatt ${ }^{{ }^{*}}$ and Krishna Y. Pandya ${ }^{1,2}$ \\ ${ }^{1}$ Sophisticated Instrumentation Centre for Applied Research and Testing, Vallabh Vidyanagar, \\ Gujarat-388120, India. \\ ${ }^{2}$ Department of Biology, V. P. \& R.P.T.P. Science College, Sardar Patel University, Vallabh \\ Vidyanagar, Gujarat-388120, India.
}

\begin{abstract}
Authors' contributions
This work was carried out in collaboration among all authors. Author RVP designed the study, performed the statistical analysis, wrote the protocol, and wrote the first draft of the manuscript. Author NB wrote the protocol and wrote the first draft of the manuscript and guided the analyses of the study. Author KYP helped in the literature searches. All authors read and approved the final manuscript.

Article Information

DOI: $10.9734 / A R R B / 2018 / v 30 i 430021$

Editor(s):

(1) Dr. George Perry, Dean and Professor of Biology, University of Texas at San Antonio, USA.

Reviewers:

(1) Iwona Rybakowska, Medical University of Gdansk, Poland. (2) E. Siva Rami Reddy, Tantia University, India. Complete Peer review History: http://www.sdiarticle3.com/review-history/46933
\end{abstract}

Original Research Article

Received 20 November 2018

Accepted 06 February 2019

Published 08 March 2019

\section{ABSTRACT}

The aim of the study was to find the antioxidant activity and enzyme activity of catalase and peroxidase of vegetable plants. The results indicated that the use of seaweed liquid fertilizer can enhance the antioxidant activity of Solanum melongena L., Lycopersicon esculentum Mill., Capsicum annuum L., Brassica oleracea var. Capitata L. and Allium cepa L. The 1,1-diphenyl-2picrylhydrazyl (DPPH) assays were used to determine the antioxidant properties of seaweeds by measuring the decrease in absorbance at $517 \mathrm{~nm}$. The DPPH activity was highest in brown seaweed liquid fertilizer. This study implied that impacts on vegetable plantlets by seaweed liquid fertilizer extracted with enzymes is better in brown seaweed liquid fertilizer as compared to control.

Keywords: Seaweed liquid fertiliz; antioxidant activity; catalase and peroxidase activity; vegetables.

*Corresponding author: E-mail: naina_bbhatt@yahoo.co.in, nayanabrahmbhatt67@gmail.com; 


\section{INTRODUCTION}

Vegetables and fruits are an excellent source of natural antioxidants which contain many antioxidant components that offer fortification towards free radicals and are associated with health [1]. Organic fertilizer is said to improve the antioxidant levels, while inorganic fertilizer has been tested to decrease antioxidant level in plants [2]. The fertilizer effect on vegetative growth is well documented. However, the several research have been investigated the fertilizer rates and sources on phytochemical quality in $L$. pumila Benth $[3,4,5]$, but only limited research overlaying the reaction of secondary metabolites and antioxidant activities beneath distinct fertilizer resources and rates. Applying fertilizers, especially in the inorganic form, in extra of plant necessities can increase the chances of fertilizer loss and environmental pollutants. Seaweeds extracts have been measured as prospective natural antioxidants during the last decade $[6,7$, $8,9,10,11,12,13]$. Seaweeds have turned out to be great possibility for the source of natural antioxidants due to a number of studies newly discovered $[14,15,16]$. The investigation related to natural antioxidants is motivating in more than one way because it could direct to the making of natural substitutes to potentially poisonous artificial antioxidants that are utilized in the maintenance of certain foods $[17,18]$. Seaweed extracts (SWE) provide an alternative, as they not only contain nitrogen, phosphorus, and potassium, but also present molecules with a very wide range of structures and can be composed of phytohormones or metabolically active plant extracts such as amino acids and organic acids [19,20,21]. Natural antioxidants have precautionary action in opposition to unrelieved diseases like diabetes, obesity and hypertension [22, 23]. Free radicals are liable for aging and inflicting diverse human diseases. The antioxidant activity indicates that free radicals scavenger, hydrogen-donating compounds and to oxidize metal ion play main role in the anticipation of free radical diseases [24,25,26]. Polyphenols, carotenoid and vitamin $C$ and $E$ of the major groups of phytochemicals that have been advised as a natural source of antioxidants and it enhance at low concentration of an oxidisable substrate $[27,28]$. In these study, selected vegetables of Solanum melongena L., Lycopersicon esculentum Mill., Capsicum annuum L., Brassica oleracea var. Capitata L. and Allium cepa L. antioxidant activity and enzyme activity impacted by seaweed liquid fertilizer were measured.

\section{MATERIALS AND METHODS}

Selected seaweeds such as Ulva lactuca (A1), Ulva reticulata (A2), Gracillaria corticata (A3), Kappaphycus alvarezii (A4), Sargassum johnstonii (A5) and Padina pavonica (A6) were collected from Okha port and Bet- Dwarka, Gujarat, India. Seaweeds were washed with water 3-4 time to remove other impurities and sand particles. Seaweed liquid fertilizer prepared in 1: $20(\mathrm{w} / \mathrm{v})$ ratio with water and the prepared extract was standard $100 \%$ concentrated. In this study, a mixture of both green $(A 1+A 2)$, red $(A 3+A 4)$ and brown $(A 5+A 6)$ and all selected seaweeds mixture (AM) also used and without fertilizer used as a control. In this experiment, $4 \%$ concentration was used in the antioxidant activity and enzyme activity of selected vegetables seed such as Solanum melongena L., Lycopersicon esculentum Mill., Capsicum annuum L., Brassica oleracea var. Capitata L. and Allium cepa L. Seeds were collected from Vegetable Scientific research center, Anand Agriculture University and Gandhi Agro, Anand, Gujarat.

\subsection{Antioxidant Activity-DPPH Assay}

Selected vegetable seed of Solanum melongena L., Lycopersicon esculentum Mill., Capsicum annuum L., Brassica oleracea var. Capitata L. and Allium cepa L. soaked up to 3 days and 0.1 $\mathrm{ml}$ sample extract prepared for reaction with 1, 1diphenyl-2- picrylhydrazyl (DPPH) [29]. This method is based on the ability of the antioxidant to scavenge activity and formula was:

$$
\begin{aligned}
& \% \text { Antioxidant activity } \\
& =\frac{(\text { absorbance at blank }- \text { absorbance at test })}{(\text { absorbance at blank })} \times 100
\end{aligned}
$$

\subsection{Enzyme Activity}

21 days plantlets of Solanum melongena L., Lycopersicon esculentum Mill., Capsicum annuum L., Brassica oleracea var. Capitata L. and Allium cepa L. were used for measuring the catalase and peroxidase activity of vegetables. Catalase and peroxidase activity was measured by a modified procedure $[30,31]$, respectively.

\section{RESULTS AND DISCUSSION}

\subsection{DPPH Radical Activity}

The DPPH (1,1- Diphenly -2- Picryl- hydrazyl) radical scavenging activity of the seaweed liquid fertilizers on selected different vegetable seeds shown in Fig. 2 A free radical to assess 
decreasing substance by extensively used of DPPH. The DPPH scavenging activity was observed highest in treatment of A5 seaweed liquid fertilizer such as $0.5925 \mathrm{mg} / \mathrm{g}$ followed by $0.5895 \mathrm{mg} / \mathrm{g}$ in treatment of $\mathrm{A} 5+\mathrm{A} 6$ and 0.5835 $\mathrm{mg} / \mathrm{g}$ in treatment of $A 6$ in Solanum melongena L. In Lycopersicon esculentum Mill., maximum radical scavenging activity was received from the treatment of $A 5+A 6(0.7635 \mathrm{mg} / \mathrm{g})$ followed by treatment of $A 5(0.7625 \mathrm{mg} / \mathrm{g}), A 6(0.7595 \mathrm{mg} / \mathrm{g})$ and A1 $(0.7585 \mathrm{mg} / \mathrm{g})$. Minimum antioxidant activity was concluded $0.8100 \mathrm{mg} / \mathrm{g}$ with the treatment of $A 4$ which was followed by treatment of A3+A4 $(0.813 \mathrm{mg} / \mathrm{g})$ and $A 3(0.8135 \mathrm{mg} / \mathrm{g})$ in Capsicum annum L. Similar effect was indicated in Brassica oleracea var. Capitata L. and comparison of the treatment of both Chlorophyceae seaweed liquid fertilizer A1 was highest as compared to A2. Highest radical activity was recorded in AM. that was 0.8245 $\mathrm{mg} / \mathrm{g}$ followed by $0.8230 \mathrm{mg} / \mathrm{g}$ and $0.8225 \mathrm{mg} / \mathrm{g}$ with the treatment of $\mathrm{A} 5$ and $\mathrm{A} 5+\mathrm{A} 6$, respectively. In accordance with our study, the brown seaweed contained maximum effect on DPPH radical scavenging activity than green and red seaweed $[32,33,34,35]$. The reduction of the species may be facilitated through the hydrogen donors to a free radical scavenging activity of the DPPH effective by phenolic compounds which are reduced to a nonreactive species [36], its purple colour changes fast to yellow to deposition of diminished DPPH-H (hydrogen) [25] and makes good antioxidants [37]. The water-soluble antioxidant activity was measured by DPPH assay [38]. Higher the rate of absorption, more effective is the antioxidant. The strong scavenging activity was shown in young leaves, which affected by plant phenolic compound of phytochemicals that work as a primary antioxidant [39]. The combination of phenolic, flavonoids and ascorbic acid formed a positive effect on DPPH radical scavenging activity [40, $41,42,43,44]$.

\subsection{Enzyme Activity}

Fig. 3 shows the catalase activity of all selected vegetables which was treated by seaweed liquid fertilizer. Maximum and minimum catalase activity was received with the treatment of $A 5+A 6$ and A4 seaweed liquid fertilizer that was observed $28.000 \mathrm{mg} / \mathrm{g}$ and $22.500 \mathrm{mg} / \mathrm{g}$ in Solanum melongena L. Highest catalase activity was conducted with the treatment of AM which was $25.950 \mathrm{mg} / \mathrm{g}, 26.500 \mathrm{mg} / \mathrm{g}, 26.225 \mathrm{mg} / \mathrm{g}$ and $30.250 \mathrm{mg} / \mathrm{g}$ found in Lycopersicon esculentum Mill., Capsicum annum L., Brassica oleracea var. Capitata L. and Allium cepa L., respectively. Minimum catalase activity was concluded with the treatment of A4 in Lycopersicon esculentum Mill., Capsicum annum L., Brassica oleracea var. Capitata L. and Allium cepa L. that was 20.100 $\mathrm{mg} / \mathrm{g}, 21.700 \mathrm{mg} / \mathrm{g}, 20.900 \mathrm{mg} / \mathrm{g}$ and 20.950 $\mathrm{mg} / \mathrm{g}$, respectively but it was higher than the

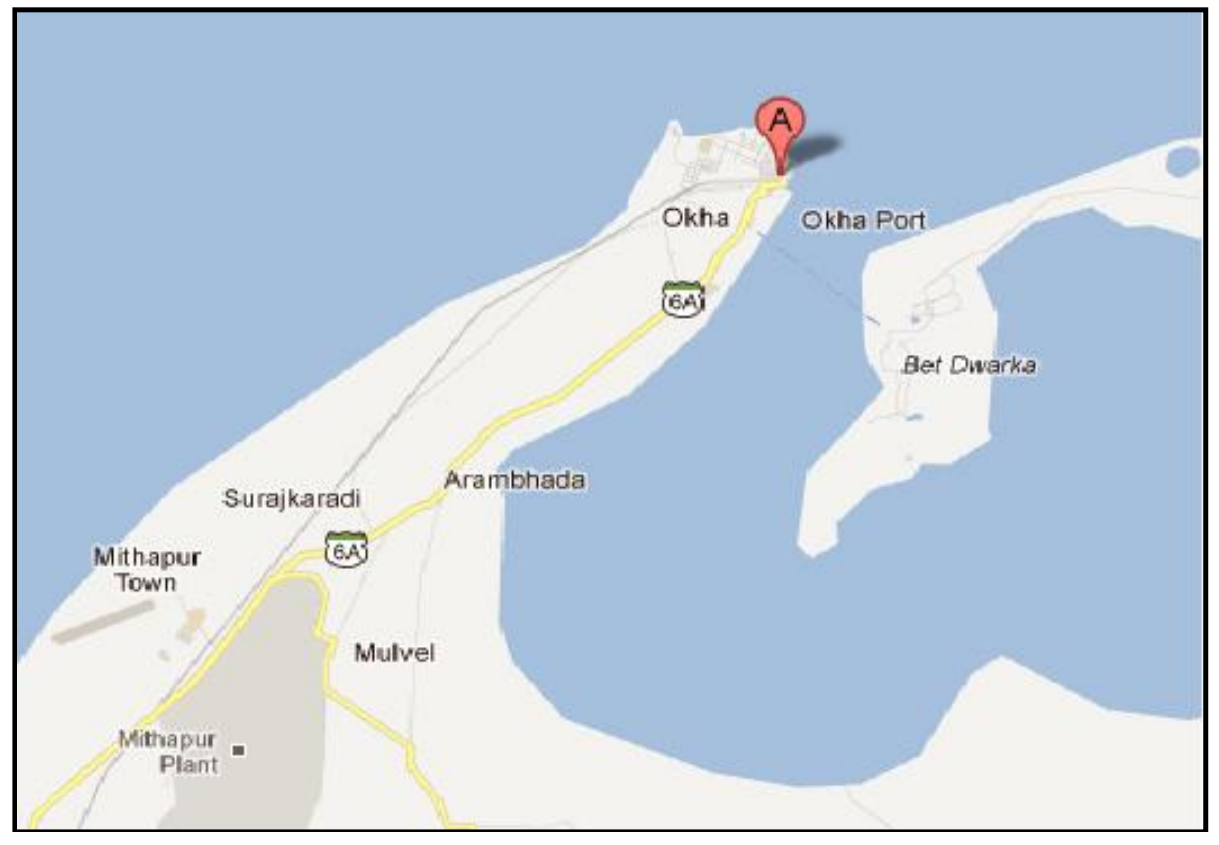

Fig. 1. Map of collection site (Source of Google) 


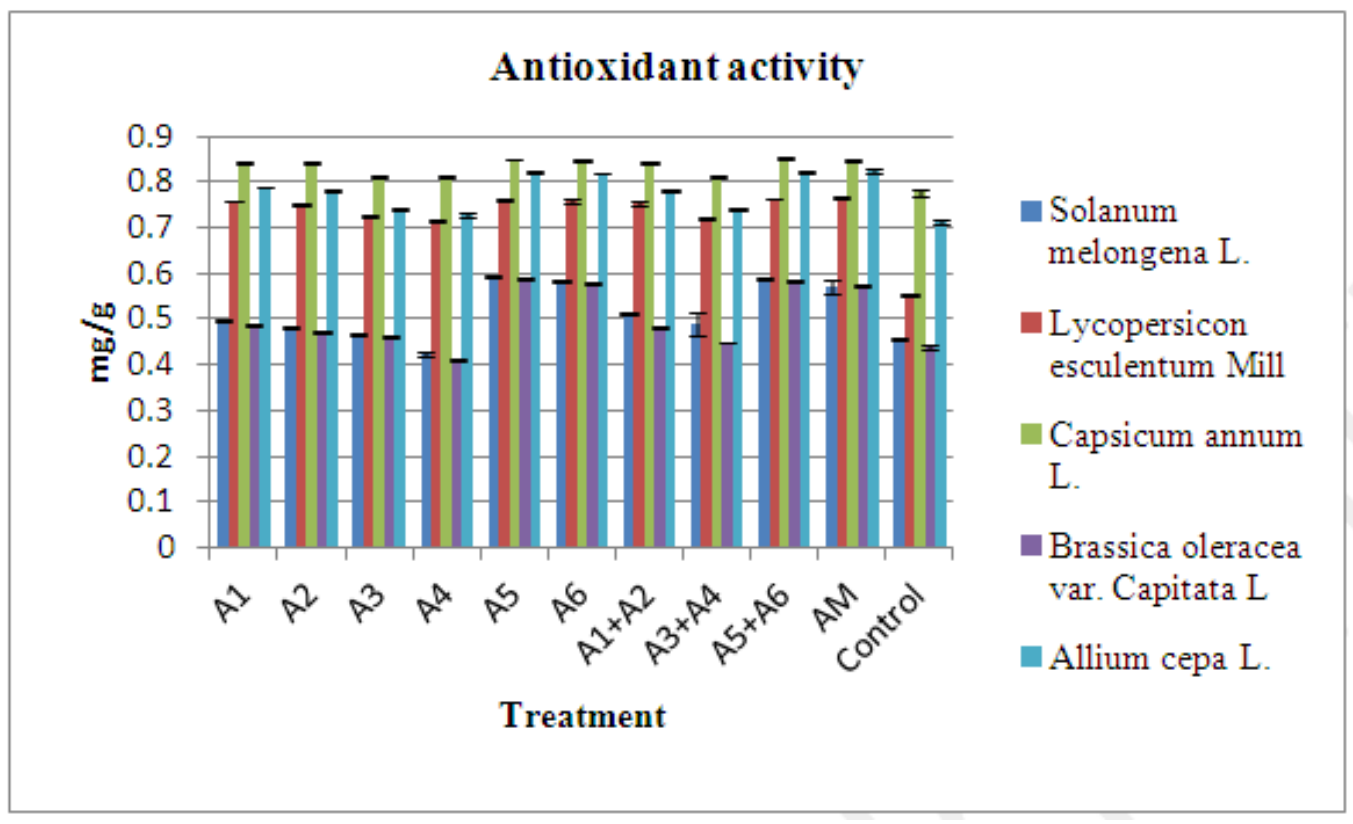

Fig. 2. Effect of different seaweed liquid fertilizer on DPPH radical activity of selected vegetable seeds

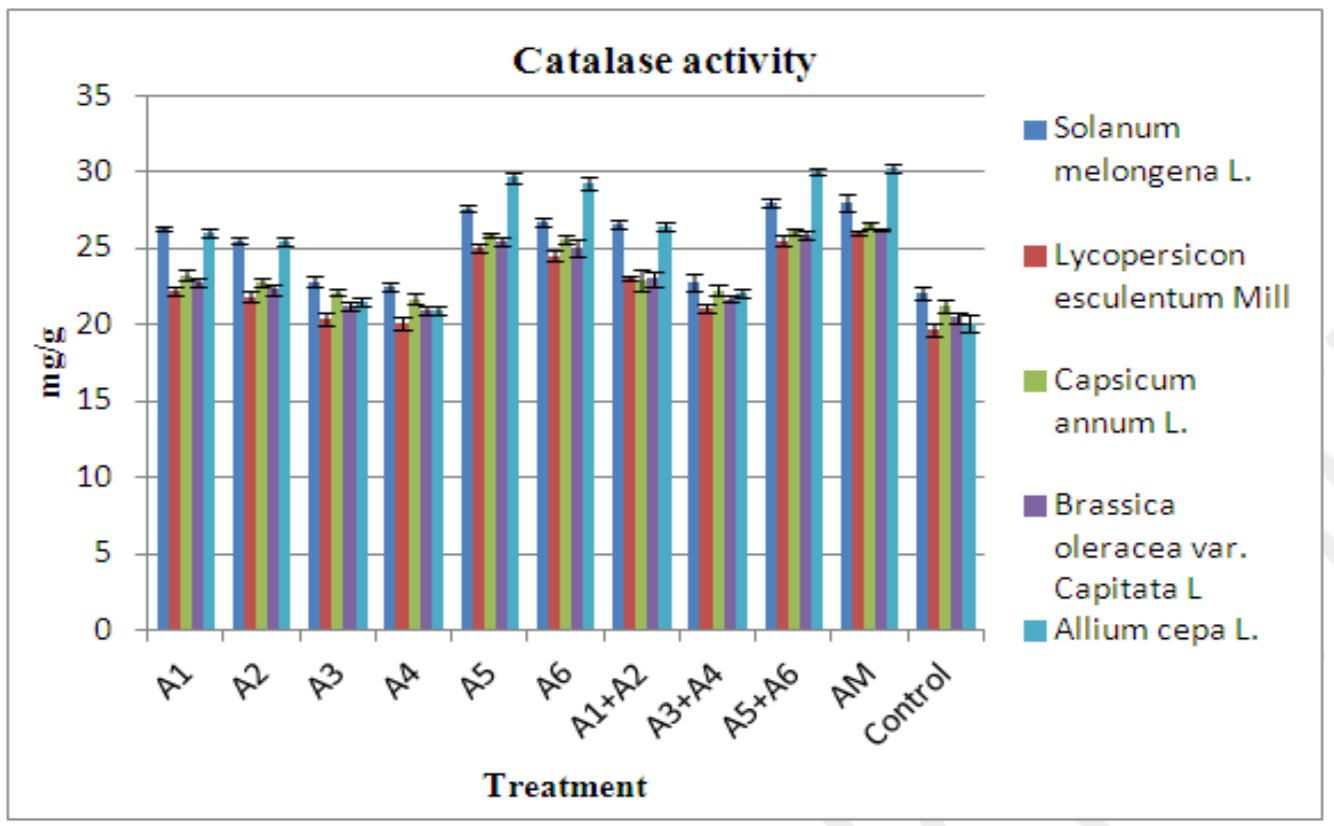

Fig. 3. Effect of different seaweed liquid fertilizer on catalase activity of selected vegetable seeds

control. Fig. 4 shows the peroxidase activity of vegetables. Minimum activity was found with the treatment of A4 seaweed liquid fertilizer that was recorded $0.950 \mathrm{mg} / \mathrm{g}, 1.200 \mathrm{mg} / \mathrm{g}, 0.672 \mathrm{mg} / \mathrm{g}$, $0.921 \mathrm{mg} / \mathrm{g}$ and $0.659 \mathrm{mg} / \mathrm{g}$ in Solanum melongena L., Lycopersicon esculentum Mill.,
Capsicum annum L., Brassica oleracea var. Capitata L. and Allium cepa L., respectively. Maximum peroxidase activity was received with the treatment of AM that was calculated 1.624 $\mathrm{mg} / \mathrm{g}, 1.675 \mathrm{mg} / \mathrm{g}, 1.506 \mathrm{mg} / \mathrm{g}, 1.594 \mathrm{mg} / \mathrm{g}$ and $1.688 \mathrm{mg} / \mathrm{g}$, respectively. 


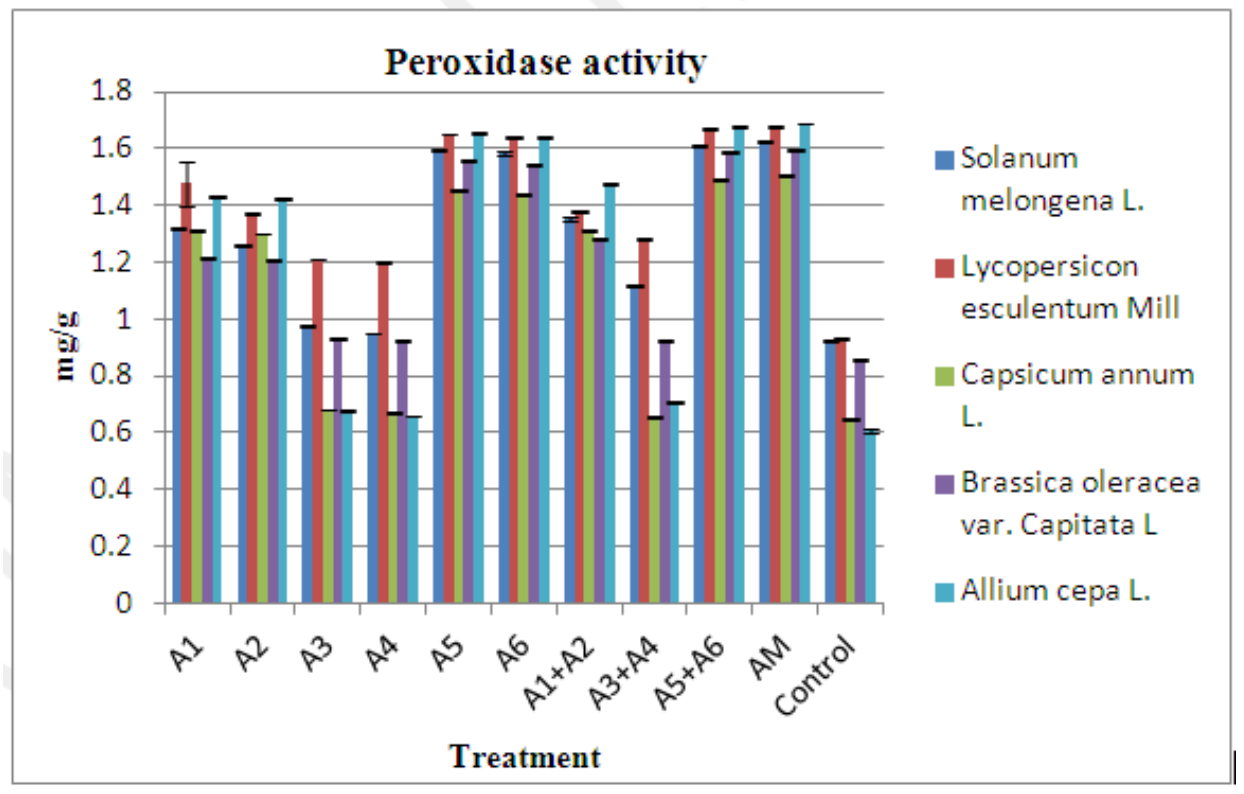

Fig. 4. Effect of different seaweed liquid fertilizer on the peroxidase activity of selected vegetable seeds

Lowest percentage of germination can be decreased in enzyme activity [45,46,47,48]. Enzyme activities of catalase, peroxidase and glutathione peroxidase were concluded maximum with the treatment of seaweed liquid fertilizer on Helianthus annuus L. [49] and Zea mays [50]. The catalase enzyme is closely interconnected with peroxidase in its structure and function and both enzyme formed during oxidative metabolism and in the oxidation used $\mathrm{H}_{2} \mathrm{O}_{2}$ from alcohol, phenol and another hydrogen donor [51]. Catalase and peroxidase activity observed in Vigna [52] and in pumpkin [53]. Seaweed extract treatment increased peroxidase, catalase and superoxide dismutase activities of wheat $[54,55,56,57]$. The affirmative effect micronutrient of $\mathrm{Zn}$ of seaweed extract on antioxidant enzymes activity [58]. Seaweed extract was enhanced the antioxidant enzyme activity in pea [59], in cotton [60] and in barley [61]. The peroxidase activity was enhanced by the production of oxygen species in plant tissue [62]. The DPPH radical scavenging activity of every sample in different seaweeds extracts used would affect the radical scavenging activity [63].

\section{CONCLUSION}

The study noticeably indicates the antioxidant activity using DPPH radicals while evaluating the antioxidant potential of vegetable plantlets extracts and significant value of antioxidant activity was found in brown seaweed liquid fertilizer. This study concluded the seaweed liquid fertilizer to enhance the antioxidant activity and enzyme like catalase and peroxidase activity of vegetable plant. The principle of this concept is basically to apply a method that is environmentally friendly and favourable for human interest as well.

\section{COMPETING INTERESTS}

Authors have declared that no competing interests exist.

\section{REFERENCES}

1. Velioglu YS, Mazza G, Gao L, Oomah BD. Antioxidant activity and total phenolics in selected fruits, vegetables, and grain products. Journal of Agricultural and Food Chemistry.1998;46:4113-4117.

2. Dumas $Y$, adomo M, Lucca G, Grolier P, Lucca $G$. Effects of environmental factors and agricultural techniques on antioxidant content of tomatoes. Journal of the Science of Food and Agriculture. 2003;83: 369-382.

3. Ibrahim $\mathrm{MH}$, Jaafar HZE, Asmah $\mathrm{R}$, Zaharah AR. Involvement of nitrogen on flavonoids, glutathione, anthocyanin, ascorbic acid and antioxidant activities of 
Malaysian medicinal plant Labisia pumila Blume (Kacip Fatimah). Int $\mathrm{J}$ Mol Sci. 2012;13:393-408.

4. Jaafar $\mathrm{HZ}$, Ibrahim $\mathrm{MH}$, Karimi $\mathrm{E}$. Phenolics and flavonoid compounds, phenylanine ammonia lyase and antioxidant activity responses to elevated $\mathrm{CO}_{2}$ in Labisia pumila (Myrisinaceae). Molecules. 2012;17:6331-6347.

5. Ibrahim $\mathrm{MH}$, Hawa ZEJ. Carbon dioxide fertilization enhanced antioxidant compounds in Malaysian Kacip Fatimah (Labisia pumila Blume). Molecules. 2011; 16:6068-6081.

6. Anggadiredja J, Andyani R, Hayati, Muawanah. Antioxidant activity of Sargassum polycystum (Phaeophyta) and Laurencia obtuse (Rhodophyta) from Seribu Islands. J. Appl. Phycol. 1997;9: 477-479.

7. Yan XJ, Nagata T, Fan X. Antioxidative activities in some common seaweeds. Plant Foods for Hum. Nutrit. 1998;52:253262.

8. Duval B, Shetty K, Thomas WH. Phenolic compounds and antioxidant properties in the snow alga Chlamydomonas nivalis after exposure to UV light. J. Appl. Phycol. 2000;11:559-566.

9. Xue $\mathrm{CH}$, Fang $\mathrm{Y}$, Lin $\mathrm{H}$, Chen L, Li ZJ, Deng D, Lu CX. Chemical characters and antioxidative properties of sulfated polysaccharides from Laminaria japonica. J. Appl. Phycol. 2001;13:67-70.

10. Ruberto G, Baratta MT, Biondi DM, Amico $\mathrm{V}$. Antioxidant activity of extract of the marine algal genus Cystoseria in a micellar model system. J. Appl. Phycol. 2001;13: 403-407.

11. Kovatcheva EG, Koleva II, llieve M, Pavlov A, Mincheva M, Konushlieva M. Antioxidant activity of extracts from Lavandula vera MM cell cultures. Food Chem. 2001; 72:295- 300.

12. Ruperez P, Ahrazem O, Leal JA. Potential antioxidant capacity of sulfated polysaccharides from the edible marine brown seaweed Fucus vesiculosus. J. Agric. Food. 2002;50:840-845.

13. Lim SN, Cheung PCK, Ooi VEC, Ang PO. Evaluation of antioxidative activity of extracts from brown seaweed, Sargassum siliquastrum. J. Agric. Food Chem. 2002; 50:3862-3866.

14. Fujimoto K, Kaneda T. Separation of antioxygenic (antioxidant) compounds from marine algae. Hydrobiologia. 1984; 116/117:111-113.

15. Cahyana $\mathrm{AH}$, Shuto $\mathrm{Y}$, Kinoshita $\mathrm{Y}$. Pyropheophytin a as an antioxidative substance from the marine alga, Arame (Eisenia bicyclis). Biosci Biotechnol Biochem. 1992;56:1533-1535.

16. Lee JH, Park JC, Choi JS. The antioxidant activity of Eclonia stolonifera. Arch. Pharm. Res. 1996;19:223-227.

17. Lako J, Trenerry VC, Wahlqvista M, Wattanapenpaiboona N, Sotheeswaran S. Phytochemical flavonols, carotenoids and the antioxidant properties of a wide selection of Fijian fruits, vegetables and other readily available foods. Food Chemistry. 2007;101:1727-1741.

18. Koala M, Hema A, Somé $K$, Palé $E$, Sérémé A, Belem J, Nacro $M$. Evaluation of eight orange fleshed sweet potato varieties for their total antioxidant, total carotenoid and polyphenolic contents. Journal of Natural Sciences Research. 2013b;3:67-72.

19. Valencia TR, Sánchez Acosta L, Fortis Hernández $M$, Preciado Rangel $P$, Gallegos Robles M, Antonio Cruz R, Vázquez Vázquez $C$. Effect of seaweed aqueous extracts and compost on vegetative growth, yield, and nutraceutical quality of cucumber (Cucumis sativus L.) Fruit. Agronomy. 2018;8(11):264.

20. Santiago-López G, Preciado-Rangel $P$, Sánchez-Chávez $E$, Esparza-Rivera JR, Fortis-Hernández $M$, Alejandro MorenoReséndez A. Organic nutrient solutions in production and antioxidant capacity of cucumber fruits. Emir. J. Food Agric. 2016; 28:518-521.

21. Yehia YIA, El-Miniawy SEDM, El-Azm NAA, Hegazi AZ. Response of snap bean growth and seed yield to seed size, plant density and foliar application with algae extract. Ann. Agric. Sci. 2016;61:187-199.

22. Renaud SC, Guéguen R, Schenker J, d'Houtaud A. Alcohol and mortality in middle-age men from Eastern France. Epidemiology. 1998;9:184-188.

23. Willcox JK, Ash SL, Catignani GL. Antioxidants and prevention of chronic diseases. Critical Reviews in Food Science and Nutrition. 2004;44:275-95.

24. Jadhav SJ, Nimbalkar SS, Kulkarni AD, Madhavi DL. Lipid oxidation in biological and food systems. In: Food antioxidants. Madhavi DL, Deshpande SS, Salunkhe DK (eds). New York; 1995. 
25. Yamagushi $\mathrm{T}$, Takamura $\mathrm{H}$, Matoba $\mathrm{T}$, Terao J. HPLC method for evaluation of the free radical scavenging activity of foods by using 1, 1,- diphenyl- 2-picrylhydrazyl. Biosci Biotech and Bioche. 1998;62:12011204.

26. Okawa M, Kinjo J, Nohara T, Ono M. DPPH (1,1-Diphenyl-2-Picrylhydrazyl) radical scavenging activity of flavonoids obtained from some medicinal plants. Boil Pharm Bull. 2001;24:1202-1205.

27. Halliwell B, Aeschbach R, Ltliger J, Aruoma OI. The characterization of antioxidants. Food and Chemical Toxicology. 1995;33:601-617.

28. Latique S, Chernane $\mathrm{H}$, Mansori M, El Kaoua M. Seaweed liquid fertilizer effect on physiological and biochemical parameters of bean plant (Phaesolus vulgaris variety Paulista) under hydroponic system. European Scientific Journal, ESJ. 2013;9(30).

29. Brand-Williams W, Cuvelier M, Berset C. Antioxidant activity determined using stable radical, 1,1-diphenyl-2picrylhydrazyl (DPPH), LebensmittelWissens-chaft- und Technology. 1925;28: 25.

30. Barber, J.M., Estimation of catalase. Z. Pflazen Phsiol, 1980; 97: 135.

31. Sumner, J.B., and Gjessing, E.C. A method for the determination of peroxidase activity. Archives of Biochemistry, 1943; 2: 291-293.

32. Jiménez-Escrig $A$, Jiménez-Jiménez I, Pulido R, Saura-Calixto F. Antioxidant activity of fresh and processed edible seaweeds. Journal of the Science of Food and Agriculture. 2001;81(5):530-534.

33. Devi KP, Suganthy $N$, Kesika $P$, Pandian SK. Bioprotective properties of seaweeds: In vitro evaluation of antioxidant activity and antimicrobial activity against food borne bacteria in relation to polyphenolic content. BMC Complementary and Alternative Medicine. 2008;8(1):38.

34. Wang $\mathrm{Y}, \mathrm{Xu} \mathrm{Z}$, Bach SJ, McAllister TA. Sensitivity of Escherichia coli to seaweed (Ascophyllum nodosum) phlorotannins and terrestrial tannins. Asian-Australasian J. Anim. Sci. 2009;22:238-245.

35. Zubia M, Fabre MS, Kerjean V, Le Lann K, Stiger Pouvreau V, Fauchon M, Deslandes E. Antioxidant and antitumoural activities of some Phaeophyta from Brittany coasts. Food Chemistry. 2009b;116(3):693-701.
36. Wang J, Wu FA, Zhao H, Liu L, Wu QS. Isolation of flavonoids from mulberry (Morus alba L.) leaves with macroporous resins. African J of Biotech. 2008;7:21472155.

37. Michalak A. Phenolic compounds and their antioxidant activity in plants growing under heavy metal stress. Polish $\mathrm{J}$ of Env Studies. 2006;15:523-530.

38. Frankel EN, Huang SW, Kanner J, German JB. Interfacial phenomena in the evaluation of antioxidants: Bulk oils versus emulsions. J. Agric. Food Chem. 1994;42: 1054-1059.

39. Hatano T, Ogawa N, Kira R, Yasuhara T, Okuda T. Tannins of cornaceous plants. In Cornusiins $A, B$ and $C$, dimeric, monomeric and trimeric hydrolysable tannins from Cornus offcinalis, and orientation of valoneoyl group in related tannins. Chemical and Pharmaceutical Bulletin. 1989;37:2083-2090.

40. Glenn MI, Thomas-Barberan FT, HessPirce B, Kader AA. Antioxidant capacities, phenolic compounds, carotenoids and vitamin $\mathrm{C}$ contents of nectarine, peach and plum cultivars from California. J. Agric. Food Chem. 2002;50:4976-4982.

41. Ghasemzadeh A, Hawa ZE, Jaafar Rahmat. A antioxidant activities, total phenolics and flavonoids contentin two varieties of Malaysia young ginger (Zingiber officinale). Molecules. 2010;15: 4324-4333.

42. Ghasemzadeh A, Jaafar HZE. Effect of CO2 enrichment on synthesis of some primary and secondary metabolites in ginger (Zingiber officinale Roscoe). Int. J. Mol. Sci. 2011;12:1101-1114.

43. Ibrahim MH, Jaafar HZE. Abscisic acid induced changes in production of primary and secondary metabolites, photosynthetic capacity, antioxidant capability, antioxidant enzymes and lipoxygenase inhibitory activity of Orthosiphon stamineus Benth. Molecules. 2013;18:7957-7976.

44. Ibrahim MH, Jaafar HZE. Relationship between extractable chlorophyll content and SPAD values in three varieties of kacip fatimah under greenhouse conditions. J. Plant Nutr. 2013;36:13661372.

45. McDonald MB. Orthodox seed deterioration and its repair, In: Handbook of seed physiology: Applications to Agriculture. Benech-Arnold RL, Sanchez 
RA (Eds.). Food Products Press, New York. 2004;273-304.

46. Bailly C. Active oxygen species and antioxidants in seed biology. Seed Sci Res. 2004;14:93-107.

47. Kibinza S, Bazina J, Bailly C, Farrant JM, Corbineaua $\mathrm{O}$, Bouteaua $\mathrm{H}$. Catalase is a key enzyme in seed recovery from aging during priming. Plant Science. 2011;181: 309-315.

48. Tabatabaei SA. The effect of priming on germination and enzyme activity of sesame (Sesamum indicum L.) seeds after accelerated aging. J of Stress Physiology \& Biochemistry. 2013;9(4):132-138.

49. Akila $\mathrm{N}$, Jeyadoss $\mathrm{T}$. The potential of seaweed liquid fertilizer on the growth and antioxidant enhancement of Helianthus annuus L. Oriental Journal of Chemistry. 2010;26(4):1353-1360.

50. Asir Selin Kumar, Effie A, Saravanababu S. Studies on the effect of seaweed and seagrass liquid fertilizers on the fruit length and weight of Abelmoschus esculentus L. Var. Hybrid-10. Seaweed Res.Utlin. 2007; 29(1-2):101-103.

51. Dilley R.D. Enzymes. In: The biochemistry of fruit and their products. Ed. Hulme AC, Academic Press, London and New York. 1970;179-204.

52. Linga Kumar K, Jeyaprakash Manimuthu RC, Haribaskar A. Gracillaria edulis an effective alter native source as a growth regulator for legume crops. Seaweed Res and Utili. 2002;24(1):117-123.

53. Bellis LD, Nishimura M. Development of enzyme of the glyoxalate cycle during senescence of pumpkin cotyledons. Plant Cell Physiol. 1991;32(4):555-561.

54. Sharaf AM. Improvement growth and yield of wheat plants grown under salinity stress by using silicon. J of Ameri Sci. 2010; 6(11):559-566.

55. Hemida KA, Ali RM, Ibrahim WM, Makram AS. Ameliorative role of some antioxidant compounds on physiological parameters and antioxidants response of wheat (Triticum aestivum L.) seedlings under salinity stress. Life Science Journal. 2014; 11(7):324-342.

56. Kasim WA, Hamada EAM, Shams El-Din NG, Eskander SK. Influence of seaweed extracts on the growth, some metabolic activities and yield of wheat grown under drought stress. Int J Agri R. 2015;7:173189.

57. Ibrahim WM. Potential impact of marine algal extracts on the growth and metabolic activities of salinity stressed wheat seedlings. J of Applied Sci. 2016;16(8): 388-394.

58. Tavallali V, Rahemi M, Eshghi S, Kholdebarin B, Ramezavian A. Zinc alleviates salt stress and increases antioxidant enzyme activity in the leaves of pistachio (Pistacia vera L. Badami) seedlings. Turk. J Agri. 2010;34:349-359.

59. Hernandez JA, Campillo A, Jimenez A, Alacon JJ, Sevilla F. Response of antioxidant systems and leaf water relations to $\mathrm{NaCl}$ stress in pea plants. New Phytol. 1999;141:241-251.

60. Meloni DA, Oliva MA, Martinez CA, Cambraia J. Photosynthesis and activity of superoxide dismutase, peroxidase and glutathione reductase in cotton under salt stress. Env Exp Bot. 2003;49:69-76.

61. Fayez KA, Bazaid SA. Improving drought and salinity tolerance in barley by application of salicylic acid and potassium nitrate. Journal of the Saudi Society of Agricultural Sciences. 2014;13:45-55.

62. Okuda T, Matsuda Y, Yamanaka A, Sagisaka S. Abrupt increases in the level of hydrogen peroxide in leaves of winter wheat is caused by cold treatment. Plant Physiol. 1991;97:1265-1267.

63. Marinova EM, Yanishlieva NV. Antioxidative activity of extracts from selected species of the family Lamiaceae in sunflower oil. Food Chem. 1997;58:245248.

(c) 2018 Patel et al.; This is an Open Access article distributed under the terms of the Creative Commons Attribution License (http://creativecommons.org/licenses/by/4.0), which permits unrestricted use, distribution, and reproduction in any medium, provided the original work is properly cited.

Peer-review history:

The peer review history for this paper can be accessed here: http://www.sdiarticle3.com/review-history/46933 